\title{
A critique of the drive towards the globalization of higher education
}

\author{
David Bird and Brian Nicholson \\ Information Technology Institute, University of Salford
}

\begin{abstract}
In this paper, we argue that global, technology-driven higher education may not be addressing issues that impact on the effectiveness of learning for differing people across the planet. It is necessary to explore the rationale for such globalization, and consider the optimistic proponents of this trend, as well as the drivers, benefits, and higher educational arguments that exist for its development. There are a number of technological advances that have allowed for the development of a global marketplace in higher education, and issues relating to technology-shaping society point to a number of social choice arguments and problems with technology-driven global education. The notion of financially motivated 'global pillage' is evidenced by courses franchized into developing countries. The importance of crosscultural diversity shows how some technology-based global learning systems may be failing to address the cultural context of education. The role of the global media industry delivering a morass of 'informing' trivia available across the Internet questions Broadcast Only/Push Technology and identifies the issue of education overload. The globalization of higher education should stress the importance of the tools for developing countries that provide self-produced appropriate higher education for themselves, and remove cynical profiteering.
\end{abstract}

\section{An introduction - why globalize?}

There has been an increase in the level of commerce that transcends national boundaries. Businesses no longer rely on local markets as acceptable, safe areas to do business. The emphasis is on globalization. Failing to globalize will result in the decline of a commercial activity, and a 1990 survey among businesses found that 40 per cent of them considered the expansion of the global market required increased production capacity and speed (Peppard, 1993).

Globalization has been heralded by the development of free trade associations. All of these developments have been founded on the basis of international trade, with some associations going further in their evolution than others. The growth in genuine global trade has undoubtedly been influenced by the impact of information technologies. The increase in cross-border financial transactions has been eased through newly introduced financial systems. New technology means that mass produced goods can be customized to suit a particular market (Wheelwright and Clark, 1992), evident in industries as diverse as car and software development. 
Education has shown parallels. British education has always attracted an overseas audience. Anecdotal evidence shows that many overseas students come from former British colonies, as well as the Gulf States and China.

Why this interest in British education? Is the UK system of higher education among the best in the world? Former colonial states have systems of education (along with civil services) based on a UK model, allowing for easier integration of learning, and an available pathway. UK red-brick universities have been noted for engineering and research reputation, vital skills in a developing country.

Cost, distance, and time away from home have been barriers to entry for all but a few privileged individuals. The vast majority of overseas students who study in the UK do so because they can afford it through personal wealth, or through rare financial aid. Despite high numbers of overseas students studying in UK universities, the percentage of students from each country who have the opportunity to study is small. It seems important to make learning available to more students in particular overseas countries. Historically, this has been difficult and costly. Approaches to home-country learning have included visiting lecturers and franchised courses.

The first choice relies on availability (and willingness) of academics for overseas duties. There are issues relating to travel, cost and time. An academic overseas is not available as an academic at home, causing concern at the home institution. Franchisement poses different problems, discussed later.

The need to encourage learning overseas still exists. The quality of learning experience that UK academia provides could be extremely high. The existing need for skills in engineering and sciences can only be a benefit for emerging economies if such a need is fulfilled.

There are other factors that spur UK institutions into developing courses in emerging economies. UNESCO (1995) reports that higher education should consider pro-activity in an international environment. Gordon (1995) notes that traditional 'cottage industry' lecturing academics are disappearing, replaced by more efficient and effective ways of dissemination. As American-led fast-food outlets have globalized eating habits and consumption, so the development of a postmodern McUniversity emerges to lead learning consumption (Ritzer 1996). Here is the development of 'education as a product' (Plater, 1995) rather than a difficult-to-define something else. A product can ultimately be sold!

\section{Technology for mass education}

There are issues that determine the nature of global education relating to the evolution of the university environment in the next century:

- university education as a mass production system;

- information technology for distance learning;

- the 'consuming' of education.

Communications and network technologies already impact on the development of mass global education. There are a number of courses that are offered via the Internet, and the US experience of delivering undergraduate courses is highly developed (Brittingham and 
Cook, 1995). The consumerist outlook of students means that the delivery of learning has become akin to other daily experiences, such as surfing on the Internet, channel-hopping on television, or eating fast food (Ritzer, 1996). Plater (1995) recognizes that Western students are becoming consumers who see education as a product.

To add to the increasing 'consumption' of education, technologies such as broadcast media, mixed-media CD-ROM, cable television, and the World Wide Web have allowed the beginnings of entertainment-based education. Academics have partnered with communication businesses such as CNN and MTV to produce materials for global distribution.

Plater (1995) suggests that:

Technology will change forever the dominant model of synchronous, time-linked interaction that has made teaching and learning complementary and interdependent. Learning will no longer depend on a faculty member's teaching.

This suggests that the movement of knowledge becomes a one-way affair. Interaction with academics becomes almost zero. Students become expected to produce work on their own. There is a level of impersonality associated with this mode of education: the reward is lower costs.

\section{The critique}

The purpose of this critique is to develop an anti-narrative of the story. The reader needs to develop a sensible judgement about the validity or not of the pregnant concept of global distance learning. The argument focuses around the role of education in a global network, tacit knowledge and discussions about cultural imperialism. It is necessarily provocative. The intention is to raise issues around whether the globalization of education via technology-based distance learning is at best a naïve technological fix and at worst an example of an extreme form of capitalism riding on a wave of technological utopianism.

It can be argued that educational institutions are capturing the 'wave' of technological optimism in order to exploit an opportunity, and that this leads to an impoverished education. Iacono and Kling (1996) remark that, increasingly, computer technologies are linked to all socially valuable behaviour, and are singled out as the panacea of all social problems. Technology is seen as enabling an efficient means by which 'education' can be delivered anywhere in the world, requiring the commodification of education via;, for instance, a technological fix of distance learning via the Internet. It is questionable whether this 'product' can represent education rather than simple training. Many aspects of knowledge are regarded as tacit (Polyani, 1973; Schon, 1983). It is well known that tacit skills can be transferred only through a process of socialization (master to apprentice). In a technology-based distance learning environment, when time and space separate the learners, it is questionable where and when this process of socialization will happen to enable the learners to draw on this source of tacit knowledge. This approach to education implies a view of the learner as a 'black box', limiting education to the exchange of concrete explicit symbols, reducing the experience to vocational training.

Sir Ron Dearing (1997) makes the point that franchising agreements between British universities and those in other countries have been seen to fail. Courses that are franchised 
out to educational establishments overseas suffer from poorer-quality levels of teaching due to academics that are not as able as those in the home country. Levels of quality assurance may not be as stringent due to the hands-off nature of franchise management. Students taken on by the franchise might not be as able as those taken on by the UK University, and this can have adverse effects on issues such as the reputation of qualification. Anecdotal evidence suggests that the educational experience of students on overseas franchised courses does not match that of overseas students who come to study in the UK. There are few guarantees that similar débâcles will not occur with the delivery of education to developing countries via technology. Similarly there are no guarantees in a free market that quality products will emerge and customers will appreciate that what they are buying is not 'education' from a British university. In the absence of standards, there is complete reliance on the ethics of the education-providers in delivering an appropriate quality 'product' for their developing country-based 'customers'. Examples of profiteering exist, with disturbing evidence that foreign universities in India prefer to team up with professional institutes that are not part of the higher-education system. These attract rich students of less merit, and degrees are often unrecognized (Powar, 1997).

\section{Education as a cultural force}

What about the problematic notion of cross-cultural education via technology-based distance learning? Education is viewed by many as reinforcing the cultural underpinnings of a nation state. Dearing (1997) points out that education is a 'guardian or transmitter of culture'. The school education system in particular is seen both as the structural foundation for a culture, and as providing an awareness of a large proportion of the 'social glue' of society.

Nations attribute great relevance to education policy. Witness the attention given to the National Curriculum in the UK and debates over assessment and discipline. Higher education has a somewhat different tradition, but historically reflects the power relations and level of individuality of a culture.

Nations in the developing world fear the increase of cultural, economic and political imperialism by powerful developed nations, and the loss of language and traditional ways of life. The Macbride report on the New World Information and Communication Order (NWICO) in 1980 sought to bring about a more equitable system of information flows between developed and developing nations. The ability of foreign broadcasters to beam poor-quality TV and satellite into countries regardless of the wishes of a country is a warning of the implications of unregulated education via the Internet. This can only offer variable quality in tandem with a threat to cultural integrity, which could be described as electronic cultural imperialism (Martin 1995).

\section{Problems of technology-based distance learning across cultures}

The final argument draws on the work of Hofstede (1992) who has been concerned with understanding cultural differences between nations. This research has been used by a large number of studies into cross-cultural dimensions of organizations (Kedia and Bhagat, 1988; Erez and Earley, 1993), and has been shown to be useful for thinking about national cultural issues across disciplines. These findings should provoke discussion concerning the problematic nature of cross-cultural education using technology-based distance learning. 
The Hofstede framework includes the following dimensions of national culture:

- Power distance has to do with the extent to which people expect their superiors to think for them, the inequality of power between higher- and lower-level persons, and the degree to which that inequality is accepted.

- Uncertainty avoidance has to do with the extent to which the members of a culture feel threatened by uncertain or unknown situations, and the extent to which future possibilities are defended against or accepted.

- Individualism has to do with the relative importance of individual goals compared with group goals and the degree of interdependency among members of a society

- Masculinity has to do with the extent to which a society values achievement of results, heroism, assertiveness and material success. In a masculine society, sympathy is with the winner and fighters; feminine cultures indicate more sympathy with the meek and underdog. Masculine societies are said to 'live to work', feminine societies 'work to live'.

Each dimension is typified by particular characteristics and each country is categorized on the extent to which the population exhibits these characteristics on a sliding scale from high to low. This allows direct comparisons and tentative indications of the dominant national characteristics of a given group reflecting what Hofstede refers to as 'mental programming'.

Consider Hofstede's remarks on education within 'power distance' and 'individualism':

Power Distance. In a large power-distance situation in countries such as Malaysia or India, the educational system is highly personalized especially at university. What is transferred is not impersonal truth but the personal wisdom of the teacher. The power of inspiration is key; the teacher is known as a 'guru' in India and Indonesia, a term derived from Sanskrit for 'weighty' or 'honourable'. This term defines the relationship, seen as spiritual and personal with the quality of learning wholly dependent on the teacher. This contrasts with small power distance cultures such as the USA or Britain where the educational process is student-centred, with a premium on student initiative and with students finding their own intellectual paths. The emphasis is on personal initiative, and it is one which is common in the design assumptions of technology-based distance learning, as the teacher and learner are separated by time and space. Designs rely on self-motivation and a culturally developed sense of independence, absent in a large power distance country.

Individualism. Consider Hofstede's comments on individualism and collectivism. Collectivist countries include countries such as Malaysia, Taiwan and Korea; individualist countries include Britain, the USA and Canada. A typical complaint from teachers of students from collectivist countries is that they do not speak up in class and will also hesitate to speak up in larger groups, it being seen as inappropriate to speak up without the sanction of the group. This is seen as problematic particularly if the technology-based distance learning attempts to incorporate some innovation such as groupware to overcome the problems of participation. There is a danger that students will again not contribute in ways expected by the educator. Hofstede points out crucial differences with regard to the purpose of education between individualist and collectivist societies: 
In the former it aims at preparing the individual for a place in a society of other individuals. This means learning to cope with new unknown unforeseen situations. There is basically a positive attitude to what is new. The purpose of learning is less to know how to do as to know how to learn. In the collectivist society there is a stress on adaptation to skills and virtues necessary to be an acceptable group member. Learning is seen as a one-time process to learn how to do things in order to participate in society.

National philosophy and character of learning are viewed as different between cultures. Interestingly, those countries that are high on both of the dimensions mentioned include Taiwan, Korea, Malaysia and Singapore, supposedly ripe markets for distance education. Smith (1993) found that there were real problems that came to light when distance-learning technologies were used in India. Issues he identified included:

- rigidity in the learning model (i.e. the model for learning was not flexible enough for the variety and culture of learners);

- poor accessibility;

- a failure to be accepted as rigorous in the academic world.

\section{Conclusions and implications for the development of cross-cultural distance learning}

We have addressed a number of issues regarding the globalization of higher education, and have considered the motivation for global higher education, problematic issues of quality, the role of education, tacit knowledge and arguments on cross-cultural issues.

There is the need for standards of quality for technology-assisted distance education, especially when delivered to other countries, and for course designers to be sensitive to differing learning styles across cultures, and to consider tailoring materials via collaborative development and providing local support for the learning process.

From a pessimistic perspective it could be argued that the globalization of education is being carried on a wave of techno-optimism coupled with a scramble to exploit new markets. From a pragmatic perspective this uncritical view of the potential of global higher education poses significant threats to the future integrity and reputation of Western technology-assisted distance learning.

\section{References}

Brittingham, B. and Cook, C.M. (1995), 'Evaluating institutions of higher learning in the cybernetic age,' Proceedings of the Second Quality Assurance in Education Conference, Manchester.

Dearing, R. et al (1997), Higher Education in the Learning Society, Report of the National Committee of Inquiry into Higher Education, London: NCIHE Publications (HMSO), July.

Erez, M. and Earley, P. (1993), Culture, Self-identity and Work, New York: Oxford University Press. 
Gordon, G. (1995), 'Higher Education 2005: pointers, possibilities, pitfall, principles', Quality Assurance in Education, 3, 21-9.

Hofstede, D. (1992), Cultures and Organisations, London: McGraw-Hill.

Iacono, S. and Kling, R. (1996), 'Computerisation movements and tales of technological utopianism' in Kling, R. (ed), Computerisation and Controversy, London: Academic Press, 85-105.

Kedia, B. and Bhagat, R. (1988), 'Cultural constraints on transfer of technology across nations: implications for research in international and comparative management', Academy of Management Review, 13 (4), 559-71.

Martin, W. (1995), The Global Information Society, Aldershot: Gower.

Peppard, J. (1993), IT Strategy for Business, London: Pitman.

Plater, W. M.(1995), 'Future work: faculty time in the 21st century', Change, 27, 23-33.

Polyani, M. (1973), Personal Knowledge: Towards a Post-Critical Philosophy, London: Routledge.

Ritzer, G. (1996), 'McUniversity in the postmodern consumer society'; Quality in Higher Education, 2 (3), 185-99.

Schon, D. (1983), The Reflective Practitioner, New York, Basic Books.

Smith, K. (1993), Developments in Distance Education in Asia: An Analysis of Five Case Studies, Paris: UNESCO.

Powar, K. B. (1997), 'Excellence is an island', The Times Higher, 29 August, 11.

UNESCO (1995), Policy Paper for Change and Development in Higher Education, Paris: UNESCO.

Wheelwright, S. C. and Clark, K. B. (1992), 'Creating project plans to focus product development', Harvard Business Review, March-April, 70=82. 